\title{
A Randomized clinical trial on Ardhavabhedaka-Migraine and its Ayurvedic management
}

\author{
Research Article
}

\section{Vaghela DB ${ }^{1}$, Shweta Mata ${ }^{2 *}$, Dhiman $\mathrm{KS}^{3}$, Manjusha $\mathrm{R}^{4}$}

\author{
1. Assistant Professor, 2. Phd Scholar, 4. Professor \& HOD \\ Department of Shalakya Tantra, IPGTRA, Gujarat Ayurved University, Jamnagar. \\ 3. Director General, CCRAS, New delhi.
}

\begin{abstract}
Ardhavabhedaka defines Ardha Mastak Vedana. The word migraine is derived from the Greek word hemicranias, meaning "half of the head". Migraine is now recognized as a chronic illness, not simply a headache. Many medications have been tried and a lot are still in research work also, but modern drugs are not acceptable due to their drawbacks. In contrast to that Ayurveda has a variety of natural medication in the treatment of Ardhavabheda$k a$. It was planned to compare the result between Laghu Sutashekhara Rasa orally in Group A, Brihat Dashamoola Taila Nasya in Group B, placebo drug in Group C and Go-ghrita Nasya in Group D. The overall effect of therapy showed that in Group A 38\% patients cured and 36\% patients got marked improvement. In Group B 46.67\% patients moderately improved and 35.55\% patients marked improved. In Group C 90\% patients unchanged. In Group D $48.89 \%$ patients moderately improved and $28.89 \%$ patients marked improved. No any adverse drug reaction was found during whole study. Total 150 patients were registered and from the results and observation which were received from this study it can be concluded that Group A is showing better results in Ardhavabhedaka.
\end{abstract}

Key Words: Brihat Dashmoola Taila, Go-ghrita, Laghu Sutashekhara Rasa, Nasya.

\section{Introduction:}

Headache has troubled mankind from dawn of civilization. Neurovascular headaches are the second most common primary headaches, which includes migraine(1). The term "migraine" refers to a syndrome of vascular spasms of the cranial blood vessels. Migraine is now recognized as a chronic illness, not simply a headache(2). Many medications have been tried and a lot are still in research work also, but modern drugs are not acceptable due to their drawbacks. All the medications, either the older one or the newly available one have a lot of side effects (GIT distress, etc). In contrast to that Ayurveda has a variety of natural medication in the treatment of various types of Shiro-Roga. Thus, here an attempt has been made to evaluate the efficacy of Shamana Yoga - Laghu Sutashekhara Rasa from Rasa Tarangini(3), which is having digestive, anti-oxidant, anti-inflammatory properties and Vata-Kaphahara quality of Gairika, Shunthi and Betel leaves. As a Shodhana therapy Brihat Dashamoola Taila from Bhaisajya Ratnavali(4), which is having Vatahara properties, has been selected in the present study.

\footnotetext{
*Corresponding Author:

Shweta Mata

$\mathrm{PhD}$ scholar,

Department of Shalakya Tantra,

IPGT\&RA, Gujarat Ayurved University,

Jamnagar -361008.

E-mail: shwetamatadr@gmail.com
}

According to Acharya Sushruta(5), Ardhavabhedaka is best treated with Ghrita and it is effective in subsiding Pittaja and Vataja disorders; it improves Dhatus and is overall booster for improving Ojas.

So here the clinical study has been planned to find out the efficacy of Brihat Dashamoola Taila and Goghrita as Nasya and Laghu Sutashekhara Rasa as oral drug in comparison of placebo drug for the treatment of Ardhavabhedaka

\section{Aims and objectives:}

The present study was based on following aims and objects:

To study the etiopathogenesis of Ardhavbhedaka - Migraine from Ayurvedic and modern point of view.

To evaluate the efficacy of Laghu Sutashekhara Rasa (orally) and Brihata Dashamoola Taila (Nasya) in patients suffering from Ardhavabhedaka - Migraine.

\section{Materials and methods:}

For clinical study, patients attending O.P.D. \& I.P.D. of Department of Shalakya, I.P.G.T. \& R.A., hospital fulfilling the criteria for diagnosis were selected randomly, irrespective of their Desha, Jati, Prakriti, Sattva etc. Patients' written informed consent was taken before starting the treatment. The study was conducted in 150 subjects. CTRI reg. no. is 2015/07/009321. The study was approved by Institutional Ethics Committee (No.PGT/7/A/Ethics/2011-12/2687 dated on 23/08/2011).

\section{Diagnostic criteria:}

Criteria for inclusion: Age Control group between 16 
to 60 years and having sign and symptom of Ardhavabhedaka (Migraine) according to Ayurvedic Classics as well as Modern science. The diagnosis of the disease shall be done on the basis of clinical manifestations like recurrent attacks of headache, mostly unilateral in site, variable in intensity, frequency and duration with or without nausea, vomiting, aura and GI tract symptoms.

\section{Criteria for exclusion:}

Sinusitis, hypertension, fever, Secondary headache caused by meningitis, tumour, encephalitis, cervical spondylitis and refractive errors. Patients using any other systemic drugs which may alter the results of study.

\section{Grouping:}

Group A: Laghu Sutashekhara Rasa: (Rasa

Tarangini Parishista)

Dose - $500 \mathrm{mg}$ Tablet thrice per day orally

Duration - 02 Months.

Group B: Brihata Dashamoola Taila for Nasya (Bhaishajya Ratnavali 65/94-98)

Dose- 6 - 8 drops in each nostril.

Duration- (02 Months) 4 sittings, each sitting of 7 days at the interval of 1 week.

Group C: Placebo Tablet prepared by wheat floor.

Dose - $500 \mathrm{mg}$ Tablet thrice per day orally Duration - 02 Months.

Group D: Go-Ghrita Nasya: (Su. U. 26/31-35)

Dose- 6- 8 drops in each nostril.

Duration- (02 Months) 4 sittings, each sitting of 7 days at the interval of 1 week.

\section{Investigations:}

Routine haematological, urine and blood sugar level analysis was carried out before treatment to rule out any disease. Digital PNS X-Ray, Ophthalmologic Fundus examination, Nasal endoscopy and CT-SCAN was done wherever required.

\section{Scoring pattern:}

\section{Subjective symptoms}

The improvement in patients was assessed on the basis of relief in the signs and symptoms of the disease. The details of the score adopted for the main signs and symptoms in this study are as follows:

Severity of Headache

$0=$ No headache.

$1=$ Mild headache, patient is aware only if he/she pay attention to it.

$2=$ Moderate headache, can ignore at times.

$3=$ Severe headache, can't ignore but he/she can do his/her usual activities.

$4=$ Excruciating headache, can't do anything.

Frequency of Headache: Assessed in term of (frequency in days)

$0=\quad$ Nil
$1=\geq 20$ days
$2=15$ days
$3=10$ days
$4=\leq 5$ days

Duration of Headache: (Assessed in term of hours/day)

$$
\begin{aligned}
& 0=\text { Nil } \\
& 1=1-3 \text { hours/day } \\
& 2=\quad 3-6 \text { hours/day } \\
& 3=6-12 \text { hours/day } \\
& 4=\quad \text { More than } 12 \text { hours/day }
\end{aligned}
$$

Nausea:

$$
0=\text { Nil }
$$

$1=$ Occasionally

$2=$ Moderate, but does not disturb the routine work

$3=$ Severe, disturbing routine work

$4=$ Severe enough, small amount of fluid regurgitating from Mouth

Vomiting:

$$
0=\text { Nil }
$$

$1=$ Only if headache does not subside

$2=$ Vomiting 1-2 times

$3=$ Vomiting 2-3 times

$4=$ Forced to take medicine to stop vomiting

Vertigo:

$0=\mathrm{Nil}$

$1=$ Feeling of giddiness

$2=$ Patient feels as if everything is revolving

$3=$ Revolving signs + black outs

$4=$ Unconscious

Aura:

$0=$ Nil

$1=$ Lasts for 5 minutes.

$2=$ Lasts for 15 minutes

$3=$ Lasts for 30 minutes

$4=$ Lasts for 60 minutes

Gradation For Associated Symptoms:
$0=\quad$ No symptoms
$1=$ Mild (can do his/her work)
$2=$ Moderate (forced to stop work)
$3=$ Severe (forced to take rest)
$4=$ Excruciating (force to take medicine)

\section{Overall assessment:}

The improvement was assessed on the basis of subjective symptoms and salivary tests (objective parameters).

\section{Subjective:}

The assessment was done by adopting the following scoring pattern for subjective symptoms-

- Complete Remission: 100\% relief in objective and subjective signs and symptoms.

- Marked improvement: 76 - 99\% relief in objective and subjective signs and symptoms.

- Moderate improvement: $51-75 \%$ relief in 
objective and subjective signs and symptoms.

- Mild improvement: 26 - 50\% relief in objective and subjective signs and symptoms.

- Unchanged: Below 25\% relief in objective and subjective signs and symptoms.

\section{Statistical estimation of results:}

The obtained data were analyzed statistically. The values were expressed as percentage of relief and Standard Error Mean. The data were analyzed by paired ' $t$ ' test. Unpaired ' $t$ ' test was applied for comparative study.

- $\quad \mathrm{P}>0.05=$ Insignificant

- $\mathrm{P}<0.05$ and $0.01=$ Significant

- $\mathrm{P}<0.001=$ Highly significant

\section{Observations and Results}

In this clinical trial of Ardhavabhedaka, a total number of 150 patients were registered and were randomly distributed into four groups. The general observations are shown in FIGURE NO. 1

Observation reveals that, regarding the chief complaints $100 \%$ patients were having Shirah-Shoola (headache), followed by Hrillas (nausea) and Bhrama (vertigo) $88 \%$ and $63.33 \%$ respectively, Chhardi (vomiting) $48 \%$, and Aura 96.66\%, which are identical to the textual Lakshana (symptoms) of Ardhavabhedaka and migraine.

Regarding the associated symptoms $77.33 \%$ patients were having Photophobia, $73.33 \%$ were having Supraorbital pain, $67.33 \%$ were having Ocular pain, $45.33 \%$ patients had blurring of vision, $27.33 \%$ had Lacrimation, $88.66 \%$ patients had sleep disturbance, $77.33 \%$ patients had Sleep disturbance, 37.33 patients had Stiffness of neck followed by other symptoms, which tally with textual Lakshana of Ardhavabhedaka and migraine.

Regarding the Shirah-Shoola, Maximum (72\%) patients were having unilateral headache, that also particularly more in parietal and frontal region i.e., $88.00 \%$ and $74.00 \%$ respectively, nature of pain was Tivra (sharp) in $66.67 \%$ patients. Regarding the quality of headache, maximum patients $(95.33 \%)$ were having Shirogaurava followed by others. The intensity of headache was Severe in $90.66 \%$ of patients. Maximum patients $(36.66 \%)$ were having chronicity of $>5$ years. Maximum patients $(88.66 \%)$ were having gradual onset of headache. The duration 3-6 hours per day of headache was seen maximum i.e., 62.66\%. Regarding frequency, the episode at an interval of $\leq 5$ days was seen maximum i.e., 51.33\%. Maximum patients $(84.66 \%)$ were found to be having continuous nature of headache. This shows that majority of the patients either have never consulted a doctor or have stopped doing so, which suggests the chronicity of disease. It was observed that patients rely on painkiller without any medical advice given by physician, in a hope to get rid of the headache quickly. But it was not going to stop the pathology. And the patients, who were taking antimigraine drugs, were not responding. This results in chronic migraines i.e., rebound or transformed migraine headache.
The maximum Nidanas (etiological factors) observed in patients were A mla A ahara (85.33), Lavana Aahara (77.33\%), Samshana (30.00\%), Adhyashna (24.66), Vishamashana (17.33\%), followed by Ratrijagarana $53.33 \%$ and Diwaswapa $71.00 \%$. This shows faulty lifestyle, which is accepted by today's generation. Intake of junk food, taking food at any time, fasting habits of females, etc lead to Agnimandhya and Tridosha Dushti, which contributes chiefly in the pathogenesis of the disease. Also tyramine and other amines present in today's junk and sour-spicy food causes dilation of the nerves in the brain, resulting in a rush of blood. Similarly Ratrijagarana (53.33) and Diwaswapa (71.33) aggravate Vata and Kapha Dosha respectively. Also disturbed sleep was observed in maximum patients i.e., 90.00\%. Disturbances such as sleep deprivation, too much sleep, poor quality of sleep and frequent awakening at night are associated with both migraine and tension headaches, whereas improved sleep habits helps in reducing the frequency of migraine headaches. Sleep also has been reported to shorten the duration of migraine headaches.

Environmental factors, like Dhupa (58.00\%), Dhuli $(36.66 \%)$, Dhuma $(26.00 \%)$ causes the Atiyoga of Indriyas and serves as a triggering factor. Female's emotional nature, the responsibilities of the family were the cause of mental factors such as Chinta $(88.66 \%)$, Krodha (64.00\%) and Shoka (06.00\%).

Wrong food and Sunlight were observed as maximum triggering factor i.e., $95.33 \%$ and $88.66 \%$ respectively. Bright lights and other high intensity visual stimuli can cause headaches in healthy subjects as well as patients with migraine headaches, but migraine patients seem to have a lower than normal threshold for light-induced pain. Sunlight, television and flashing lights all have been reported to precipitate migraine headaches.

Noise \& air pollution was observed in $82.00 \%$. Emotional (68.66\%) and physical stress (74.66\%) also acts as triggering factor. This may lead to Dhatukshaya and vitiation of Vata Dosha. Journey (74.66\%) served as triggering factor because it also leads to vitiation of Vata Dosha. Fasting habits $(60.66 \%)$ served as triggering factor because it possibly may precipitate migraine headaches by causing the release of stressrelated hormones and lowering blood sugar.

\section{Effect of therapies on signs \& symptoms}

Regarding effect of therapy on Chief complaints, group A showed significant results. Statistically highly significant $(<0.001)$ improvement in severity $(84.61 \%)$, duration $(76.92 \%)$ and frequency $(86.20 \%)$ of headache was obtained. Regarding effect of therapy on Chief complaints in group B statistically significant $(<0.01)$ improvement in severity $(77 \%)$ and highly significant $(<0.001)$ improvement in frequency $(75 \%)$ of headache. There was statistically insignificant improvement in severity (13\%), duration (14\%) and frequency $(18 \%)$ of headache in group $\mathrm{C}$. There was statistically significant $(\mathrm{P}<0.01)$ improvement in severity $(75 \%)$ and frequency $(70 \%)$ of headache in group D. TABLE NO. 1, 2, 3, 4. 
Effect of therapy on other chief complaints showed that in group A reduction of Nausea (Hrillas) $87.50 \%$ is statistically highly significant $(\mathrm{P}<0.001)$. Reduction of Vomiting (Chhardi) $89.28 \%$ is statistically highly significant $(\mathrm{P}<0.001)$. Reduction of Vertigo (Bharma) $84.37 \%$ is statistically highly significant $(p<0.001)$. Reduction of Aura $81.81 \%$ is statistically significant $(\mathrm{p}<0.01)$. Reduction of Nausea (Hrillas) $\quad 66.66 \%$ is statistically significant $(\mathrm{P}<0.01)$.Reduction of Vomiting (Chhardi) $76 \%$ is statistically highly significant $(\mathrm{P}<0.001)$. Reduction of Vertigo (Bharma) $66 \%$ is statistically significant $(\mathrm{p}<0.01)$ in group B. All the complaints are statistically insignificant at the level of $\mathrm{P}>0.10$ and $\mathrm{P}>0.05$ in group C. There was statistically significant $(\mathrm{P}<0.01)$ improvement in severity $(75 \%)$ and frequency $(70 \%)$ of headache in group D. TABLE NO. 5, 6, 7, 8.

\section{Total effect of therapy:}

The overall effect of therapy showed that in Group A 38\% patients cured and 36\% patients got marked improvement. In Group B 46.67\% patients moderately improved and $35.55 \%$ patients marked improved. In Group C 90\% patients unchanged. In Group D 48.89\% patients moderately improved and $28.89 \%$ patients marked improved. FIGURE NO. 2

The pharmacodynamics of the drug depends on its physiochemical properties, which include Rasa, Guna, Virya, Vipaka, Prabhava, etc. The mode of action of the therapy can be inferred through the relief best owed by the therapy on the exhibited symptomatology.

Chikitsa is the elimination of SampraptiPathogenesis(6). Thus the therapy selected should provide positive effect on that particular disease, presumably by acting through the alleviation of Samprapti which is the resultant of various deranged humours and their interactions.

\section{Probable mode of action of Laghu Sutashekhara Rasa:}

Action at Doshic level:

The Snigdha Guna (28.57\%), Madhura Vipaka (66.67\%), Madhura Rasa (20\%) and Ushna Virya (66.67\%) present in Laghu Sutashekhara Rasa tablet pacify the Vata Dosha.

Ruksha Guna (14.29\%), Kashaya Rasa (20\%), Madhura Rasa (20\%) and Tikta Rasa (20\%), Madhura Vipaka $(66.67 \%)$ and Sheeta Virya $(33.33 \%)$ pacify the Pitta Dosha.

Laghu Guna (14.29\%), Tikshna Guna (14.29\%), Ruksha Guna (14.29\%), Katu Rasa (40\%), Tikta Rasa (20\%), Kashaya Rasa (20\%), Katu Vipaka (33.33\%) and Ushna Virya (66.67\%) pacify the Kapha Dosha.

Action at Panchabhautika level:

Vayu (40\%) and Agni (20\%) Mahabhoota are present maximum in Laghu Sutashekhara Rasa compound drug. Vayu due to its Chalatva works as a media in Urdhavaga Pravriti and its Laghutava enhances the function of Agni Mahabhoota. Thus Deepana - Pachana Karma is also seen at Bhautika level.
Prithvi (20\%), Jala (10\%) and Akasha (10\%) provide nourishment at Bhautika level due to their Balya, Snehana and Mardavakara Karma respectively.

The compound drug is thus having Shothahara, Vedanasthapana, Deepana, Pachana, Sheeta prashamana and Tridosha Shamaka Karma.

\section{Probable mode of action of Brihat Dashmoola Taila} Nasya:

Action at Doshic level:

The Snigdha Guna (11.29\%), Guru Guna (9.68\%), Madhura Vipaka (33.33\%), Madhura Rasa (18.37\%), Lavana Rasa (4.08\%) and Ushna Virya $(85.18 \%)$ present in Brihat Dashamoola Taila pacify the Vata Dosha.

Ruksha Guna (27.42\%), Kashaya Rasa (14.29\%), Madhura Rasa (18.37\%) and Tikta Rasa $(28.57 \%)$, Madhura Vipaka $(33.33 \%)$ and Sheeta Virya (3.70\%) pacify the Pitta Dosha.

Laghu Guna (35.48\%), Tikshna Guna (12.90\%), Ruksha Guna (27.42\%), Katu Rasa (34.69\%), Tikta Rasa (28.57\%), Kashaya Rasa (14.29\%), Katu Vipaka $(66.67 \%)$ and Ushna Virya $(85.18 \%)$ pacify the Kapha Dosha.

Action at Panchabhautika level:

Vayu (38.78\%) and Agni (19.39\%) Mahabhoota are present maximum in Brihat Dasahmoola Taila. Vayu due to its Chalatva works as a media in Urdhavaga Pravriti and its Laghutava enhances the function of Agni Mahabhoota. Thus Deepana - Pachana Karma is also seen at Bhautika level.

Jala (9.18\%) Mahabhoota has Kledana and Bandhana Karma, which acts as a binding agent and Akasha (14.29\%) Mahabhoota provides proper space for the process.

Prithvi (18.37\%) Mahabhoota is having Sanghataka and Adhogamana Karma. Hence it takes back the already expelled morbid Doshas with an aim to remove them from the micro-channels.

Most of the contents in Brihat Dashmoola Taila are having Shothahara, Vedanasthapana, Deepana, Pachana and Tridosha Shamaka Karma.

\section{Probable mode of action of Go-Ghrita Nasya:}

Ghrita is supreme in Jangama Sneha and is Balavardhaka, Ojovardhaka, Vayasthapana, Agni Deepana and Dhatuposhaka. By virtue of its Sanskaranuvartana property, it attains the properties of ingredients without losing its own. According to Acharya Charaka, Ghrita is effective in subsiding Pittaja and Vataja disorders; it improves Dhatus and is overall booster for improving Ojas(7). Ghrita having Balya, Brimhana, Rasayana and Medhya effect which can be explained by two ways. Digestion, absorption and delivery to the target organ are made easy when any drug is processed with Ghrita due to its lipophilic action. Anti-oxidant effect of Go-Ghrita is due to its Vitamin A and Vitamin E content(8).

\section{Conclusion:}

Patients from 31-40 yrs of age group, females, housewives, married and middle class people were more 
prone to Migraine. Migraine sufferers had gradual onset with severe intensity and unilateral episodic pain with continuous rhythm. Triggering factors described in modern texts are the Nidanas mentioned by our ancient Acharyas. Laghu Sutashekhara Rasa is more effective than Brihat Dashamoola Taila Nasya and Go Ghrita Nasya. Laghu Sutashekhara Rasa is having significant improvement on all the parameters like Shirahshoola, Hrillas, Chhardi and on other associated symptoms of the disease Ardhavabhedaka.

\section{References:}

1) www.epainassist.com/headache/migraine/headache-or-neurovascular-headache, 21/12/2012, 16:10

2) Wolff HG. Headache and other head pain. 1st edition. New York: Oxford University Press; 1948

3) Motilal Banarasi Das. Sadananda Sharma-Rasa Tarangini (Parishista). Varanasi; $11^{\text {th }}$ edition; 2004.

4) Govind Singh Ed. Mishra S. N. Bhaishajya Ratanavali. Varanasi; Chaukhamba Surabharati Prakashana; 2005, 65/94-98.
5) Vd.Jadavaji Trikamji Acharya \& Narayana Ram Acharya. Acharya Sushruta- Sushruta Samhita Dalhana Commentary Nibandhasangraha Gayadasacharya commentary Nyayachandrika Panjika on Nidanasthana, Varanasi; Chaukhamba Surbharti Prakashana; 2008, Uttartantra 26/3135 .

6) Vd.Jadavaji Trikamji Acharya \& Narayana Ram Acharya. Acharya Sushruta-Sushruta Samhita Dalhana Commentary-Nibandhasangraha, Gayadasacharya commentary Nyayachandrika Panjika on Nidanasthana, Varanasi; Chaukhamba Surbharti Prakashana; 2008, Uttartantra 1/31-35.

7) Kashinath Shastri and Gorakha Nath. CharakaCharaka Samhita Vidyotini Hindi Commentary Varanasi; Chaukhambha Bharati Academy; Sutra Sthana 13/14.

8) Hari Sharma. The effect of ghee (clarified butter) on serum lipid levels and microsomal lipid peroxidation. Ayu. 2010 Apr-Jun; 31(2): 134140 .

FIGURE NO. 1: GENERAL OBSERVATIONS (n=150):

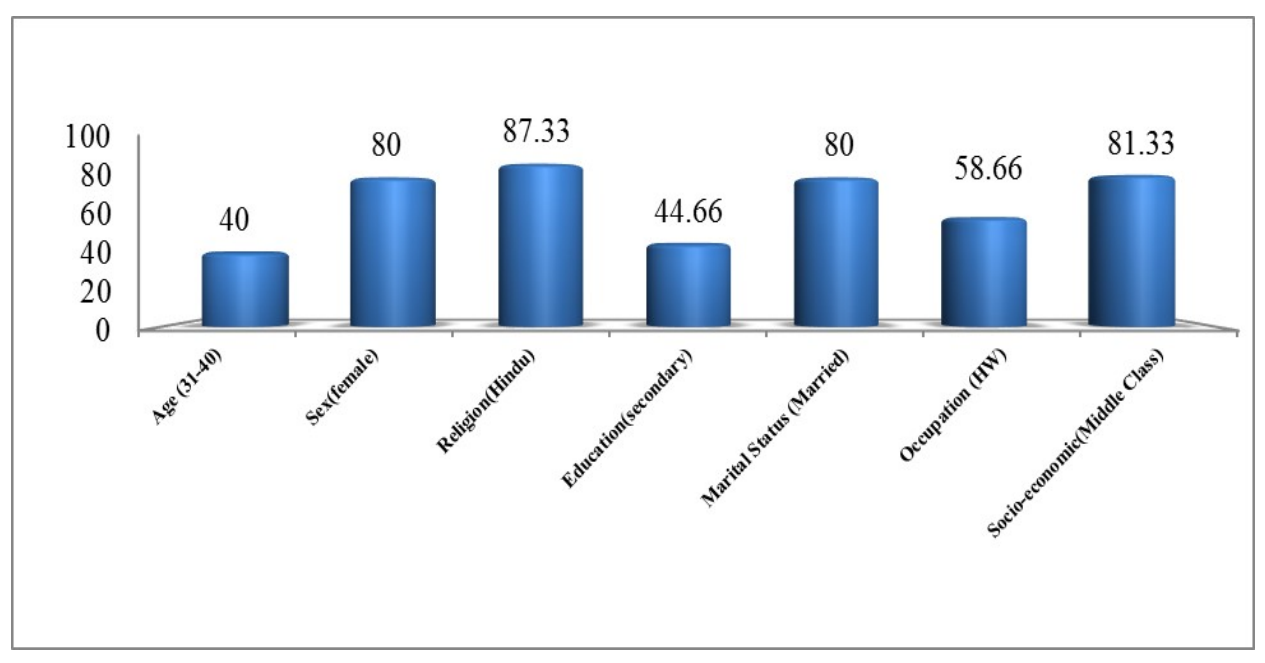

FIGURE NO. 2: OVERALL EFFECT OF THERAPY:

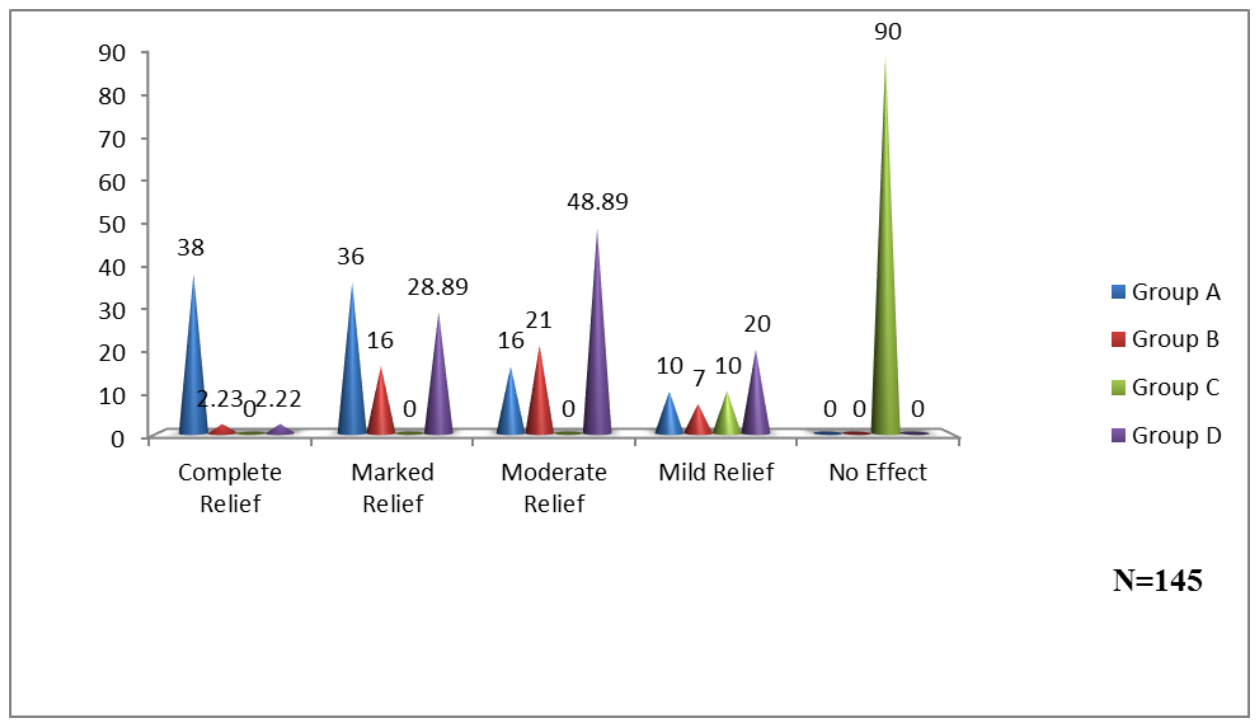


Shweta Mata et.al., A randomized clinical trial on Ardhavabhedaka-Migraine and its Ayurvedic Management

TABLE - 01: EFFECT ON HEADACHE (CHIEF COMPLAINT) IN 50 PATIENTS OF ARDHAVABHEDAKA IN GROUP A.

\begin{tabular}{|c|c|c|c|c|c|c|c|}
\hline \multirow{2}{*}{ Headache } & \multicolumn{2}{|l|}{ Mean } & \multirow{2}{*}{$\%$ of relief } & \multirow{2}{*}{$\begin{array}{c}\text { S.D. } \\
\pm\end{array}$} & \multirow{2}{*}{$\begin{array}{c}\text { S.E. } \\
\pm\end{array}$} & \multirow{2}{*}{$\mathbf{T}$} & \multirow{2}{*}{$\mathbf{F}$} \\
\hline & B.T. & A.T. & & & & & \\
\hline Severity & 02.60 & 0.4 & 84.61 & 0.141 & 0.044 & 4.90 & $<0.001$ \\
\hline Duration & 01.30 & 0.3 & 76.92 & 0.091 & 0.028 & 3.46 & $<0.01$ \\
\hline Frequency & 02.90 & 0.4 & 86.20 & 0.117 & 0.037 & 6.70 & $<0.001$ \\
\hline
\end{tabular}

TABLE - 02: EFFECT ON HEADACHE (CHIEF COMPLAINT) IN 45 PATIENTS OF ARDHAVABHEDAKA IN GROUP B.

\begin{tabular}{|c|c|c|c|c|c|c|c|}
\hline \multirow{2}{*}{ Headache } & \multicolumn{2}{|c|}{ Mean } & \multirow{2}{*}{$\begin{array}{c}\text { of } \\
\text { relief }\end{array}$} & S.D. & S.E. & T & P \\
\cline { 2 - 8 } & B.T. & A.T. & & & & $<0.01$ \\
\hline Severity & 2.2 & 0.5 & 77.27 & 0.153 & 0.048 & 3.51 & $<0.05$ \\
\hline Duration & 1.0 & 0.5 & 50.00 & 0.052 & 0.016 & 3.00 & $<0.001$ \\
\hline Frequency & 2.8 & 0.6 & 78.87 & 0.141 & 0.044 & 4.90 & $<$ \\
\hline
\end{tabular}

Table - 03: EFFECT ON HEADACHE (CHIEF COMPLAINT) IN 10 PATIENTS OF ARDHAVABHEDAKA IN GROUP C.

\begin{tabular}{|l|c|c|c|c|c|c|c|}
\hline \multirow{2}{*}{ Headache } & \multicolumn{2}{|c|}{ Mean Score } & \multirow{2}{*}{$\%$} & S.D. \pm & S.E. \pm & 't' & \multirow{2}{*}{ P } \\
\cline { 2 - 6 } & B.T. & A.T. & & & & & \\
\hline Severity & 2.2 & 1.9 & 13.63 & 0.048 & 0.015 & 1.96 & $>0.05$ \\
\hline Duration & 2.1 & 1.8 & 14.28 & 0.042 & 0.013 & 1.55 & $>0.10$ \\
\hline Frequency & 2.2 & 1.8 & 18.18 & 0.069 & 0.022 & 1.80 & $>0.10$ \\
\hline
\end{tabular}

TABLE - 04: EFFECT ON HEADACHE IN 45 PATIENTS OF $A R D H A V A B H E D A K A$ IN GROUP D

\begin{tabular}{|l|c|c|c|c|c|c|c|}
\hline \multirow{2}{*}{ Headache } & \multicolumn{2}{|c|}{ Mean Score } & \multirow{2}{*}{$\%$} & \multirow{2}{*}{ S.D. \pm} & \multirow{2}{*}{ S.E. \pm} & \multirow{2}{*}{ 't' } & \multirow{2}{*}{ P } \\
\cline { 2 - 8 } & B.T. & A.T. & & & & & $<0.01$ \\
\hline Severity & 1.6 & 0.4 & 75.00 & 0.091 & 0.029 & 4.12 & $<0.05$ \\
\hline Duration & 1.2 & 0.7 & 41.66 & 0.052 & 0.016 & 3.00 & $<0.01$ \\
\hline Frequency & 2.0 & 0.6 & 70.00 & 0.102 & 0.032 & 4.33 & $<$ \\
\hline
\end{tabular}

TABLE - 05: EFFECT ON OTHER CHIEF COMPLAINTS IN 50 PATIENTS IN GROUP A.

\begin{tabular}{|c|c|c|c|c|c|c|c|}
\hline \multirow{2}{*}{ Symptoms } & \multicolumn{2}{|c|}{ Mean } & \multirow{2}{*}{$\begin{array}{l}\% \text { of } \\
\text { relief }\end{array}$} & \multirow{2}{*}{$\begin{array}{c}\text { S.D. } \\
\pm\end{array}$} & \multirow{2}{*}{$\begin{array}{c}\text { S.E. } \\
\pm\end{array}$} & \multirow{2}{*}{$\mathbf{T}$} & \multirow{2}{*}{$\mathbf{P}$} \\
\hline & B.T. & A.T. & & & & & \\
\hline Hrillas (Nausea) & 2.4 & 0.3 & 87.50 & 0.087 & 0.027 & 7.58 & $<0.001$ \\
\hline Chhardi (Vomiting) & 2.8 & 0.3 & 89.28 & 0.117 & 0.037 & 6.70 & $<0.001$ \\
\hline Bhrama (Vertigo) & 3.2 & 0.5 & 84.37 & 0.170 & 0.053 & 5.01 & $<0.001$ \\
\hline Purvabhasa (Aura) & 2.2 & 0.4 & 81.81 & 0.125 & 0.039 & 4.54 & $<0.01$ \\
\hline
\end{tabular}


TABLE - 06: EFFECT ON OTHER CHIEF COMPLAINTS IN 15 PATIENTS OF ARDHAVABHEDAKA IN GROUP B.

\begin{tabular}{|c|c|c|c|c|c|c|c|}
\hline \multirow{2}{*}{ Symptoms } & \multicolumn{2}{|c|}{ Mean } & \multirow{2}{*}{$\begin{array}{l}\% \text { of } \\
\text { relief }\end{array}$} & \multirow{2}{*}{ S.D. } & \multirow{2}{*}{ S.E. } & \multirow{2}{*}{$\mathbf{T}$} & \multirow{2}{*}{$\mathbf{P}$} \\
\hline & B.T. & A.T. & & & & & \\
\hline Hrillas (Nausea) & 2.4 & 0.8 & 66.66 & 0.119 & 0.037 & 4.22 & $<0.01$ \\
\hline Chhardi (Vomiting) & 2.5 & 0.6 & 76.00 & 0.104 & 0.033 & 5.72 & $<0.001$ \\
\hline Bhrama (Vertigo) & 1.9 & 0.6 & 68.00 & 0.127 & 0.040 & 3.22 & $<0.01$ \\
\hline Purvabhasa (Aura) & 0.5 & 0.2 & 60.00 & 0.048 & 0.015 & 1.96 & $>0.05$ \\
\hline
\end{tabular}

Table - 07: EFFECT ON CHIEF COMPLAINTS IN 10 PATIENTS OF ARDHAVABHEDAKA IN GROUP C.

\begin{tabular}{|c|c|c|c|c|c|c|c|}
\hline \multirow{2}{*}{ Chief Complaints } & \multicolumn{2}{|c|}{ Mean Score } & \multirow{2}{*}{$\%$} & \multirow{2}{*}{ S.D. \pm} & \multirow{2}{*}{ S.E. \pm} & \multirow{2}{*}{ 't' } & \multirow{2}{*}{$\mathbf{P}$} \\
\hline & B.T. & A.T. & & & & & \\
\hline Hrillas (Nausea) & 1.8 & 1.6 & 11.11 & 0.042 & 0.013 & 1.50 & $>0.10$ \\
\hline Chhardi (Vomiting) & 1.2 & 1.0 & 16.66 & 0.025 & 0.008 & 2.44 & $>0.05$ \\
\hline Bhrama (Vertigo) & 1.6 & 1.4 & 12.50 & 0.034 & 0.011 & 1.80 & $>0.10$ \\
\hline Purvabhasa (Aura) & 1.4 & 1.1 & 21.42 & 0.042 & 0.013 & 2.25 & $>0.05$ \\
\hline
\end{tabular}

Table - 08: EFFECT OF GROUP D DRUG ON CHIEF COMPLAINTS IN 45 PATIENTS OF ARDHAVABHEDAKA

\begin{tabular}{|l|c|c|c|c|c|c|c|}
\hline \multirow{2}{*}{ Chief Complaints } & \multicolumn{2}{|l|}{ Mean Score } & \multirow{2}{*}{$\%$} & S.D. \pm & S.E. \pm & 't' & \multirow{2}{*}{ P } \\
\cline { 2 - 8 } & B.T. & A.T. & & & & \\
\hline Hrillas (Nausea) & 2.1 & 0.8 & 66.66 & 0.124 & 0.039 & 3.56 & $<0.01$ \\
\hline Chhardi (Vomiting) & 2.0 & 0.6 & 70.00 & 0.102 & 0.032 & 4.33 & $<0.01$ \\
\hline Bhrama (Vertigo) & 1.2 & 0.5 & 58.00 & 0.094 & 0.030 & 2.33 & $<0.05$ \\
\hline Purvabhasa (Aura) & 0.5 & 0.3 & 40.00 & 0.042 & 0.013 & 1.50 & $>0.10$ \\
\hline
\end{tabular}

